\title{
Detection of exposure events to environmental tobacco smoke employing portable semiconductor monitors
}

\author{
Yoshika SEKINE $^{\left.1^{*}\right)}$, Shiori OTA ${ }^{1)}$, Hiroshi SATO ${ }^{2}$, Miyuki NOGUCHI ${ }^{3)}$, Satoshi NAKAI ${ }^{4)}$ \\ and Yukio YANAGISAWA ${ }^{5}$
}

\begin{abstract}
${ }^{1)}$ Graduate School of Science, Tokai University, 4-1-1 Kitakaname, Hiratsuka, Kanagawa 259-1292, Japan
${ }^{2)}$ Faculty of Pharmaceutical Sciences, Nagasaki International University, Huis Ten Bosch-Cho 2825-7, Sasebo, Nagasaki 859-3298, Japan

${ }^{33}$ Faculty of Science and Technology, Seikei University, 3-3-1 Kichijoji-Kitamachi, Musashino, Tokyo 180-8633, Japan

${ }^{4}$ Graduate School of Environment and Information Sciences, Yokohama National University, 79-7 Tokiwadai, Hodogaya, Yokohama, Kanagawa 240-8501, Japan

${ }^{5}$ Kaisei Junior \& Senior High School, 4-2-4 Nishi-Nippori, Arakawa, Tokyo 116-0013, Japan
\end{abstract}

\section{ポータブル型半導体式モニターを用いた環境たばこ煙曝露イベントの検出}

\author{
関根嘉香 ${ }^{* *}$ ，太田 刑1)，佐藤＼cjkstart博2)，野口美由貴3)，中井里史4)，柳沢幸雄 ${ }^{5)}$ \\ 1)東海大学大学院理学研究科 干259-1292 神奈川県平塚市北金目4-1-1 \\ 2)長崎国際大学薬学部 †859-3298 長崎県佐世保市ハウステンボス町2825-7 \\ ${ }^{3}$ 成蹊大学理工学部 $=180-8633$ 東京都武蔵野市吉祥寺喜多町3-3-1 \\ 4)横浜国立大学大学院環境情報研究院 ₹240-8501 横浜市保土ヶ谷区常盤台79-7 \\ 5)開成高等学校・中学校 $=116-0013$ 東京都荒川区西日暮里4-2-4
}

\begin{abstract}
Environmental tobacco smoke (ETS) is a mixture of both gaseous and particulate matters with specific odor which affects pleasant and/or irritating sensation of human. Use of the ETS odor as a marker potentially gives a solution for evaluating a passive smoking event of non-smokers. Then, this study aimed to develop a methodology for real-time monitoring of personal exposure to ETS employing potable semiconductor monitors for odor and TVOC (Total Volatile Organic Compounds). Responses of commercially available three portable devices commercially available in Japan to the ETS were investigated in a smoker's room of an apartment house. As a reference, SPM concentrations were also measured by co-located Dust monitor. The results showed the portable monitors, except one model, successfully responded to ETS generated by smoking in indoor environment and the responses were not affected by the room mixing condition. However, the monitors were not specific to ETS; they also responded to volatile compounds originated from consumer products such as perfume and antiperspirant. Therefore, the use of gas monitor alone is not preferable for identifying exposure events to ETS. Meanwhile, one monitor, which did not respond to ETS, had sensitivity to the nonETS gases. Even though the Dust monitor was also not specific to ETS, simultaneous responses with semiconductor monitors may help to identify the ETS-oriented signals. Therefore, the combination with different monitors may reduce false detections by separating ETS and non-ETS responses in monitoring data.
\end{abstract}

\section{要 旨}

生活環境における環境たばこ煙(Environmental Tobacco Smoke, ETS)に対する曝露実態については定量的 な知見が不足しており，受動喫煙防止対策の社会的合意形成を図る上で課題となっている。本研究では ETSの「におい」に着目し，ETS曝露イベントをリアルタイムで検出するための高感度かつ携帯が容易なモ二 ター法の開発を目的としている。そこで，喫煙者が居住する集合住宅の1室において，既存のポータブル型 半導体式モニター3機種のETSに対する応答特性を調べた。その結果，用いたモニターは1機種を除き，室内 空気中のETSの経時变化を検知でき，SPM值のように室内空気の擋拌状態の影響は受けにくいことがわかっ た。ただし，香水や制汗剤など日用品の使用に伴って発生するガスにも非選択的に応答した。したがって半 導体式モニター単独ではETS曝露イベントの同定は難しいと判断された。しかしながら，応答特性の異なる センサーやデジタル粉じん計との組み合わせにより，ETS由来・非ETS由来の応答を判別できる可能性はあ る。

Key words: 環境たばこ煙(Environmental Tobacco Smoke), 受動喫煙(Passive Smoking), におい(Odor), センサー(Sensor), 曝露(Exposure)

*Corresponding author（責任著者） Email: sekine@keyaki.cc.u-tokai.ac.jp，Tel: 0463-58-1211

受付：2015年10月19日 (Received: 19 October 2015)

受理：2016年3月29日（Accepted: 29 March 2016） 


\section{Introduction}

Human exposure to Environmental Tobacco Smoke, ETS is called Passive Smoking. Adverse health risk of non-smokers caused by the passive smoking has been inviting great concerns as a public health issue on the global basis ${ }^{1)}$. However, a lack of enough quantitative data on the status of exposure to ETS makes difficult to establish a social agreement and policy for preventing the passive smoking. Our research group is currently conducting a research project entitled Comprehensive Study on the Social Acceptance of Environmental Tobacco Smoke Evaluated from the Personal Exposure and Perception. The research aims to provide fundamental data on the present status of personal exposure amount of and exposure event to ETS of Japanese people from children to the elderly with a development of monitoring methods employing portable monitoring devices.

Nicotine and its heat-induced degradation product, 3ethenylpyridine involved in tobacco smoke have been used as a specific marker for estimating personal exposure amount of ETS $^{2-4)}$. They are, however, not useful for detecting a real-time exposure event to ETS, because of its very low concentrations in air of our living environment that requires at least 24 hours of sampling duration by passive sampling method ${ }^{4,5)}$, or several hours by active (pumped) sampling method ${ }^{6,7)}$, even when coupled with highly sensitive gas chromatography. Arashidani et al. ${ }^{8)}$ had focused on particulate phase of the tobacco smoke and attempted to detect exposure events to ETS for the measurement of Suspended Particulate Matter (SPM) concentration in a smoking environment by introducing Digital Dust Monitor (Sibata Scientific Technology Ltd., Japan, LD-3K2), which determines real-time relative concentration of airborne dust ranging from $0.1-10 \mu \mathrm{m}$ of particle diameter by measuring the intensity of laser beam scattered by dust. The report said SPM concentration sharply increased when the subject was exposed to the smoke generated by a smoker. However, the monitor sometimes showed no response even when the subject was apparently aware of the tobacco odor. Therefore, they concluded that the variation of SPM concentration measured by the dust monitor does not necessarily reflect the behavior of $\mathrm{ETS}^{8)}$.

ETS has been known as a combination of mainstream and sidestream smokes which are also known as Secondhand smoke (SHS). Recently, Third-hand smoke (THS) has emerged to add to the cumulative burden of tobacco exposure, and it can be a source of ETS in indoor environment ${ }^{9,10)}$. The THS is defined as "residual tobacco smoke pollutants that remain on surfaces and in dust after tobacco has been smoked"11). The presence of malodorous airborne constituents can often be detected even after smoking ends. This suggests some of the volatile chemicals can be emitted back into indoor air from surfaces $^{9,10)}$. Hence, we focused on the gas phase of the tobacco smoke, which often cause specific odor which affects pleasant and/or irritating sensation to human, as a possible marker of the ETS exposure event.

Measurement of odor has been made by sensory test, olfactory test and/or instrumental gas analysis. In addition to them, potable semiconductor monitors have been employed as a simple alternative to the previous methods. The semiconductor monitor is a device which detects changes in electrical resistance of metal and/ or metal oxide sensors exposed to the gaseous components ${ }^{12)}$. The advantages of the use of the monitors can be singled out a real-time monitoring of odorous gases with a short-time interval. In previous laboratory tests, responses of the semiconductor monitors, so-called "Nioi sensor" in Japan, showed a good correlation with olfactory values ${ }^{13,14)}$. However, the sensors have not been fully investigated for detecting the exposure event to ETS in the living environment.

In this study, responses of three portable devices commercially available in Japan to ETS were investigated in a smoker's room of an apartment, and feasibility was discussed on the use of the semiconductor monitors for realtime monitoring of the personal exposure event to ETS, referring SPM concentrations measured by a collocated dust monitor.

\section{Method}

\section{1 Sensors used in this study}

Three kinds of portable semiconductor monitors, A, B and $\mathrm{C}$ were selected and purchased from commercial sources. Monitor A (New Cosmos Electric Co., Ltd, Japan, Portable Odor level Indicator, XP-329IIIR) is a realtime odor monitor employing an Indium oxide-based 
sensitivity hot wire semiconductor sensor with a continuous sampling by built-in air pump. Monitor B (Shinyei Technology Co., Ltd., Japan, Handheld Odor Meter, OMX-SR) employs two semiconductor gas sensors with a continuous sampling by built-in air pump. The output of the monitors A and B was displayed as dimensionless relative odor intensity defined by the manufacturers. Monitor C (Gastec Corporation, Japan, TVOC Monitor, GVC-1000) is a passive device with a heat-induced semiconductor sensor which responds to air concentration of Total Volatile Organic Compounds (TVOC) with highest sensitivity to toluene. The output is displayed as air concentration of toluene equivalent TVOC in $\mu \mathrm{g} / \mathrm{m}^{3}$. As a preliminary test, we confirmed the three monitors showed a significant response to cigarette sidestream smoke. As a reference, air concentrations of SPM (0.1 $10 \mu \mathrm{m}$ of particle diameter) were simultaneously monitored by co-located Digital Dust Monitor, Sibata LD$3 \mathrm{~K} 2$.

The monitors were calibrated before use following each instruction manual. The outputs acquired by the devices were downloaded to a personal computer and analyzed using Microsoft Excel.

\subsection{Field tests}

Field tests were conducted in a smoker's room of an apartment house located at a suburban area in Kanagawa, Japan from November 2013 to January 2014. Fig.1 shows a layout of the room and arrangement of monitors, smoker and a household mixing fan. The room is typical one bed type with a dimension of $4.2 \mathrm{~m} \times 3.0 \mathrm{~m} \times 2.5 \mathrm{~m}$ $\left(31.5 \mathrm{~m}^{3}\right)$. Air exchange rate measured by $\mathrm{CO}_{2}$ tracer decay method resulted in $0.25 / \mathrm{h}$ when the door and windows were closed. The three monitors and Dust monitor were placed on the table. The field tests were carried out following the time schedule as shown in Fig. 2.

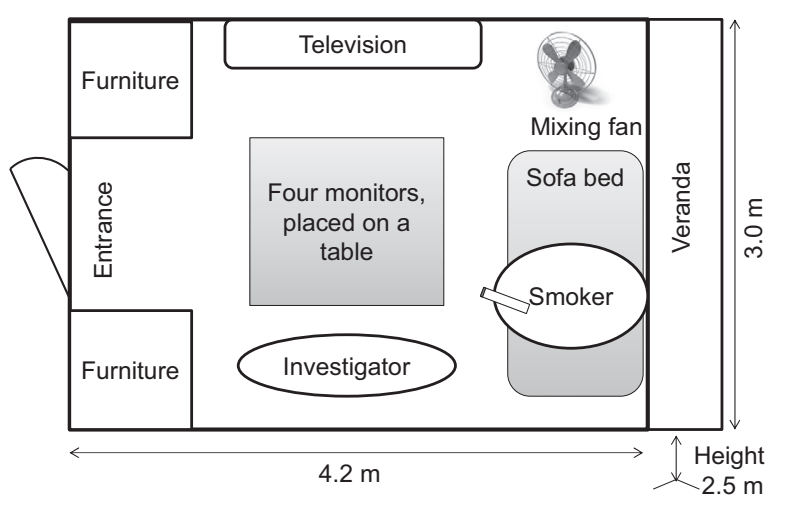

Fig.1 Layout of the field test in a smoker's apartment house

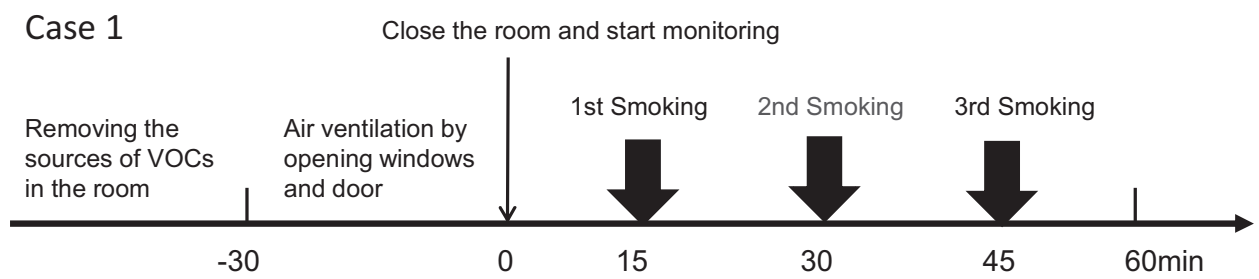

Case 2

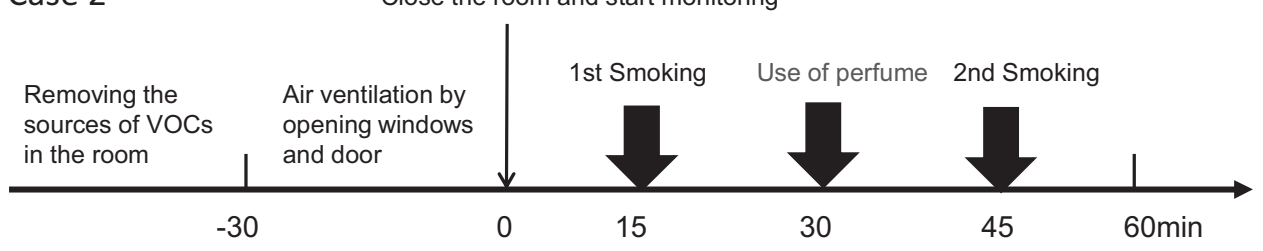

Case 3

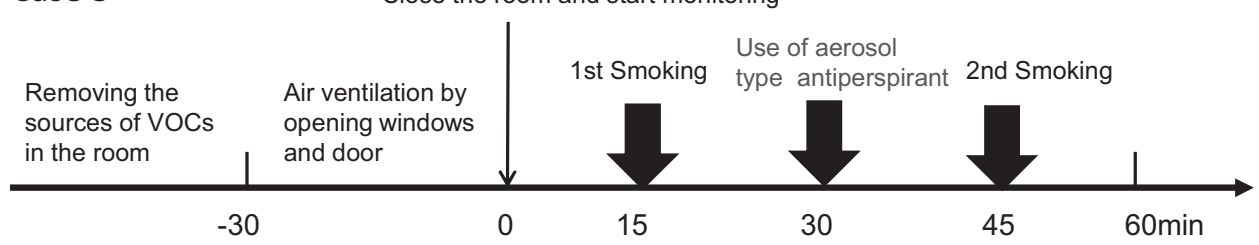

Fig.2 Time schedule of the three cases of field test in the room of smoker's apartment house 


\section{Case 1: Three repeated active smoking scenario}

Consumer products such as perfume, cosmetics and so on, which potentially emit VOCs, were removed from the room in advance. Then, the air was exchanged for 30 minutes by opening windows and door. After closing, the investigator (male, passive smoker) sit alongside the center table, and the smoker (female) smoked totally 3 pieces of tobacco (JT, Mevius super light, tar: $6 \mathrm{mg}$, nicotine: $0.5 \mathrm{mg}$ in every 15 minutes (15-min interval) during 60-min test. The smoker spent 4 minutes to finish one cigarette and puffed 4 times per cigarette. Measurement of the ETS in the room was simultaneously carried out by the three monitors and co-located Dust monitor for 60 minutes. Time-interval was set at 1-min to meet the minimum time resolution of the Monitor $\mathrm{C}$. The tests were conducted twice: with and without mixing indoor air by a fan.

Case 2: Active smoking with perfume use scenario

Alternative to second smoking at Case 1, a portion of perfume was sprayed in the room by the active smoker. All other conditions were kept the same.

Case 3: Active smoking with deodorant use scenario

Alternative to second smoking at Case 1, an aerosol type antiperspirant was flushed out in the room by the active smoker. All other conditions were kept the same.

This study was conducted under approval of Institutional Review Board, Tokai University, Japan (No. 13018).

\section{Results and discussion}

\section{1 Active smoking and influence of mixing air (Case 1)}

Results of Case 1 study were shown in Fig.3 (no mixing) and Fig.4 (with mixing). The X-axis is elapsed time during the 60 -min test, and $\mathrm{Y}$-axis is response of each device: unit-less signals by Monitors $\mathrm{A}$ and $\mathrm{B}$, toluene equivalent TVOC $\left(\mu \mathrm{g} / \mathrm{m}^{3}\right)$ concentration by Monitor C, and SPM concentration in cpm (count per minute) by the Dust monitor.

As shown in Fig.3, Monitor A and C showed significant responses to the three active smoking events. This means the both monitors successfully detected the ETS exposure events of the investigator. The baseline values gradually increased with repeated smoking. This was probably because some volatile chemicals were emitted back into air from the interior surfaces before ETS was removed completely by air ventilation. Although Monitor B showed a response to cigarette side-stream smoke, no response was observed in this field test due to lower
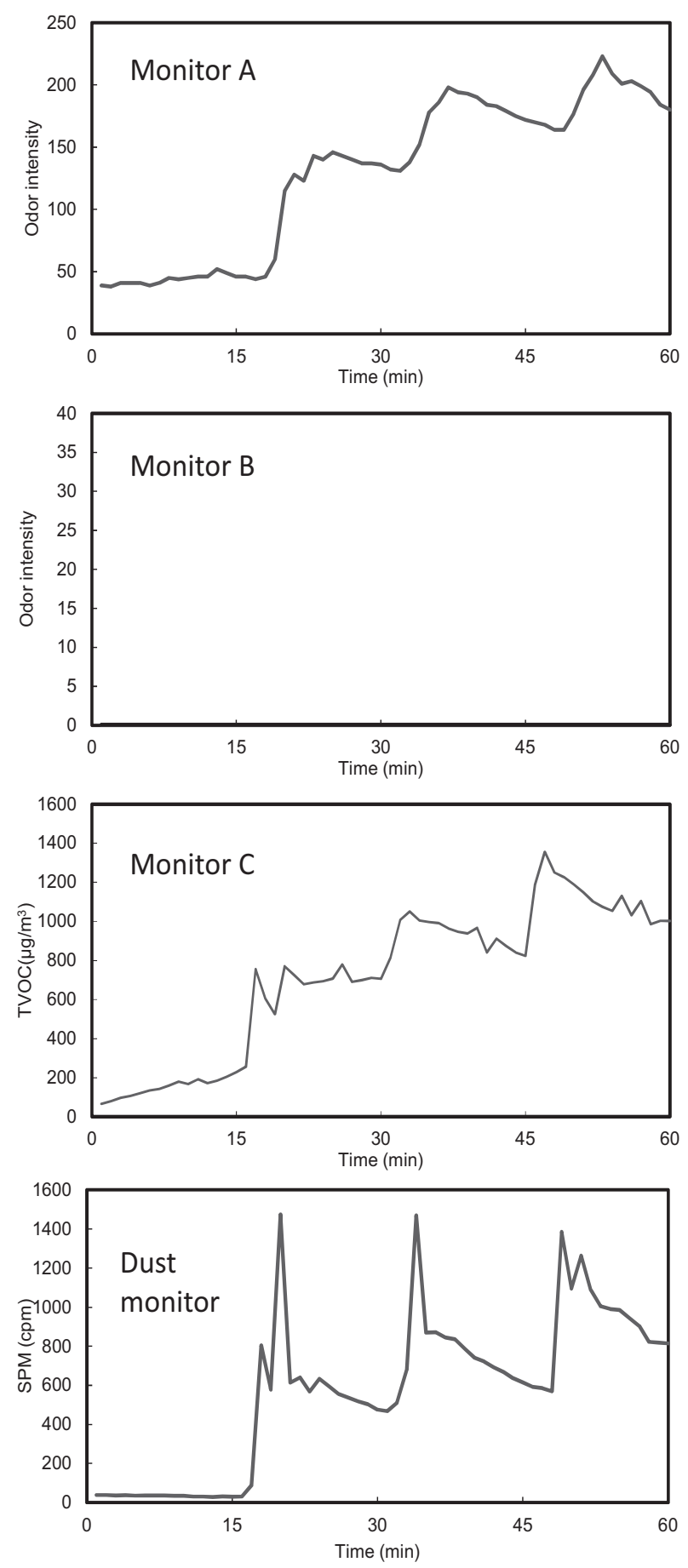

Fig.3 Responses of Monitors A, B, C and Dust monitor to ETS caused by three repeated active smoking without any forced mixing in the closed room of apartment house (Case 1, November 25, 2013). 
level of ETS in indoor air. Meanwhile, SPM concentration sharply increased with the smoking events and decreased rapidly after finishing the smoking, resulting in appearance of three sharp peaks, as was reported by Arashidani et al. ${ }^{8)}$. The baseline of SPM level also gradually increased, suggesting the particulate matter can also suspend even after the smoking ends.

The test was also conducted with mixing indoor air by a household fan (Fig.4). When air ventilation is the only loss mechanism of ETS in the room, decrease in air concentration of ETS, $C$ is described as follows;

$$
C=C^{\prime}+\left(C \mathrm{p}-C^{\prime}\right) e^{-N t}
$$

where $C^{\prime}$ is the background concentration in the room (in this case, initial value at $t=1 \mathrm{~min}$ for each monitor was applied), $C \mathrm{p}$ is the top value corresponding to three peaks, $N$ is air exchange rate $(=0.25 / \mathrm{h})$ and $t$ is time (min). Variations of $C$ calculated from equation (1) were also shown as dashed lines in Fig.4. Comparing with the model estimation, actual responses of all monitors decreased much faster. This means the air ventilation is not the only loss mechanism of both gaseous and particulate matters in the room.

Under the mixed condition, responses of Monitors A, $\mathrm{C}$ and Dust monitor showed similar time courses with a mild change in SPM concentration. This is because behavior of gases and particles in air is influenced by conditions of air flow in the environment. As generally known, gases diffuse much easier than particles in a smoking environment ${ }^{15)}$. Since particles are transported via air flow, the time course of SPM concentration was strongly affected by air flow conditions, resulting in sharp peaks under not or less turbulent (no mixing condition) and mild peaks under well-turbulent condition caused by mixing in this study. On the other hand, influence of mixing was not apparent on the responses of the gas monitors based on higher diffusivity of gas molecules. This is an advantage of the semiconductor monitor, when detecting the ETS in actual indoor environment.

To analyze a correlation between responses of semiconductor monitor and Dust monitor, cross-correlation function, $\phi_{x y}(\tau)$ was calculated as an index following equation(2).

$$
\phi_{x y}(\tau)=\frac{1}{M} \sum_{i=1}^{M} x(i) y(i+\tau)
$$

The cross-correlation is a measure of similarity of two series of data, $x(i)$ and $y(i+\tau)$ as a function of the lag time, $\tau$ of one relative to the other. In this case $x(i)$ is
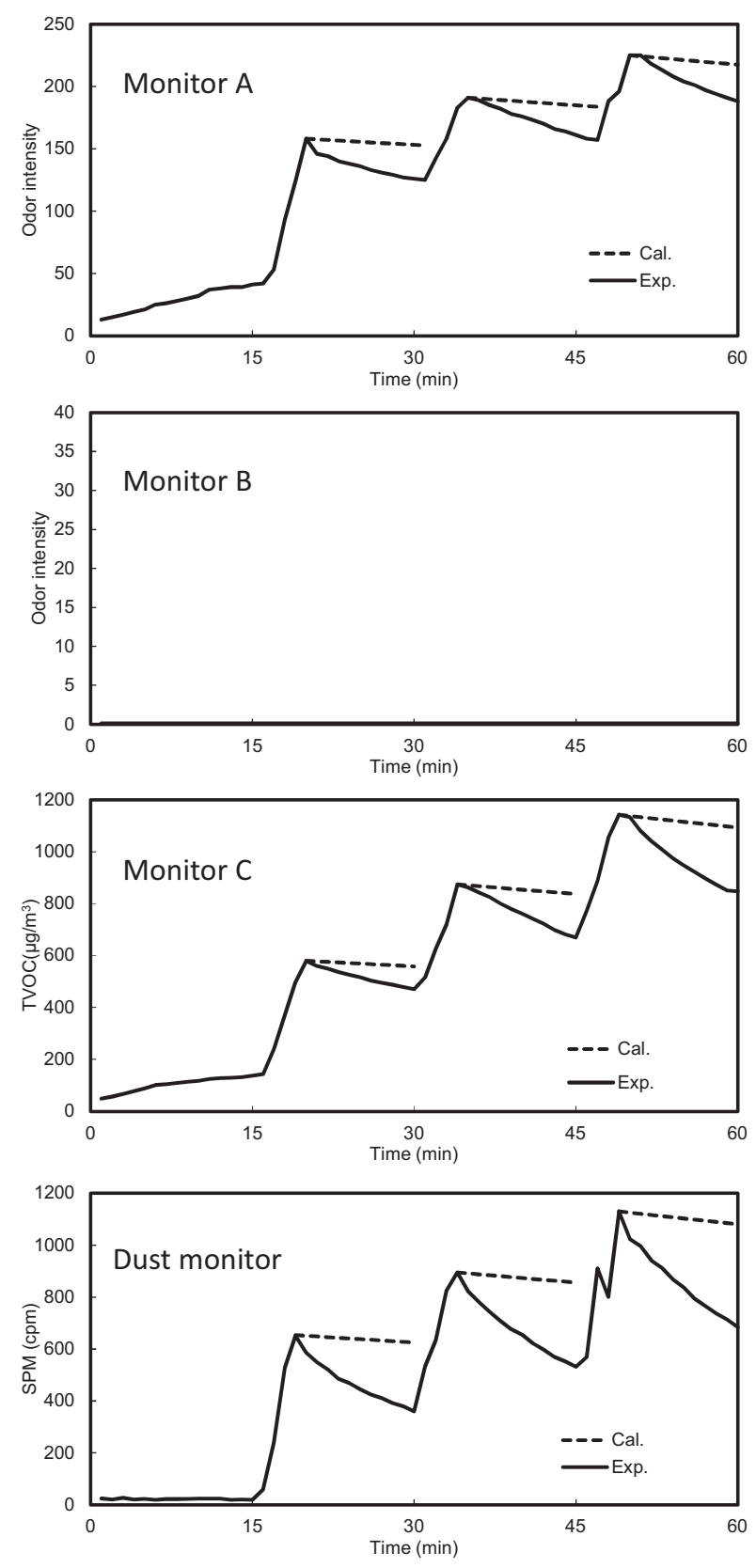

Fig.4 Responses of Monitor A, B, C and Dust monitor to ETS caused by three repeated active smoking with mixing by the fan in the closed room of apartment house (Case 1, November 25, 2013). Exp.: experimental data, Cal.: calculated time courses obtained by equation (1). 


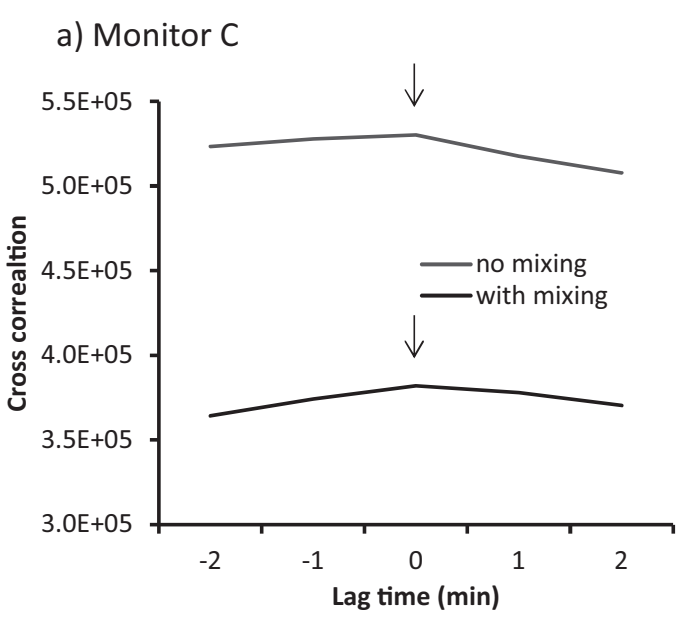

b) Monitor A

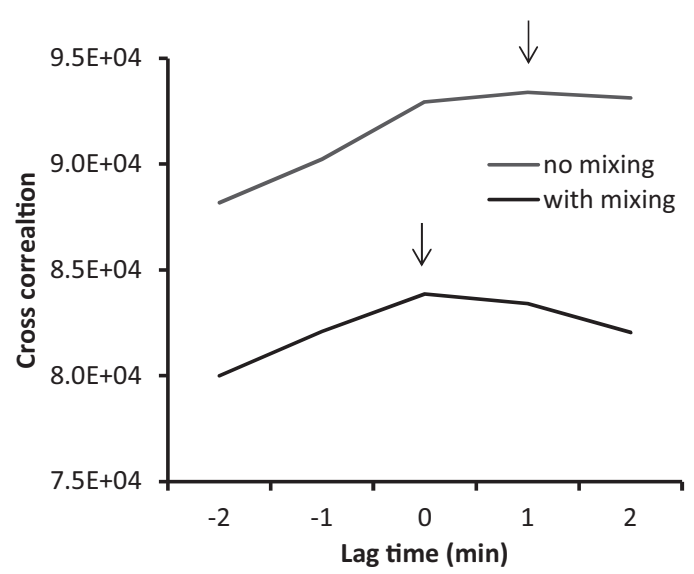

Fig.5 Cross correlation function of responses of Monitors $A$ and $C$ against those of Dust monitor to ETS caused by three repeated active smoking with and without mixing by the fan in the closed room of apartment house (Case 1, November 25, 2013).

time course of SPM concentration and $y(i+\tau)$ is that of response by Monitors A or $\mathrm{C}$ with $\tau$ of $-2,-1,0,1,2 \mathrm{~min}$. $M$ is number of data point, so $i$ ranges from 1 to 60 . Fig.5 (a)(b) shows calculated cross-correlations as a function of $\tau$. The response of Monitor $\mathrm{C}$ showed a good synchronicity with SPM concentration with a greatest value at $\tau=0$ min under both non-mixing and mixing conditions. The response of Monitor A also showed a good synchronicity under turbulent condition, whist crosscorrelation value resulted in greatest at $\tau=1$ min under non-mixing atmosphere. Since Monitor $\mathrm{A}$ is an active type monitor sucking air at a flow rate of $400 \mathrm{~mL} / \mathrm{min}$, the time difference under non-mixing atmosphere may not be caused by sampling condition of the device. Another possible reasoning is a difference in gaseous compounds which can be detected by the monitors; Monitor $\mathrm{C}$ has higher sensitivity to chemicals which has behavior similar to particulate phase of chemicals in indoor environment than Monitor A. Anyway, in view of the present purpose of this study, the good synchronicity of TVOC concentration by Monitor C with SPM concentration will be useful when alerting exposure to ETS, especially SHS.

\subsection{Active smoking and use of consumer products (Cases 2, 3)}

Fig. 6 shows monitoring results of Case 2 study with and without mixing air by the fan. Monitors $\mathrm{A}$ and $\mathrm{C}$ showed significant response even to the use of perfume, and effect of mixing air was not apparent as like smoking events. The digital particle monitor did not respond to the use of the perfume because of no emission of particulate matter from the perfume. Meanwhile, the Monitor B, which did not react with ETS, showed a quick response to the perfume components with strong signal intensities. The signals of Monitor B measured under turbulent condition (with mixing) decreased relatively faster than those measured under less turbulent filed (no mixing). This was probably due to sorption of certain portions of perfume components on the interior surface, enhanced by mixing air. The remarkable decrease was not found for the data by Monitors A and C. This means Monitor B has different selectivity and sensitivity to gaseous components from other sensors.

Fig.7 shows monitoring results of Case 3 study with and without mixing air by the fan. Since the aerosol type antiperspirant produced both gases and particulate matter, Monitor A, Monitor $\mathrm{C}$ and particle monitor responded to the use of antiperspirant in the room, and Monitor B showed a quick response to the antiperspirant only. Responses of those three semiconductor sensors were similar to those in Case 2 .

\subsection{Feasibility of semiconductor monitor method}

The responses of commercially available three portable devices to ETS were investigated in a smoker's room of an apartment house. Case I study showed Monitors A and C successfully detected the ETS generated in 

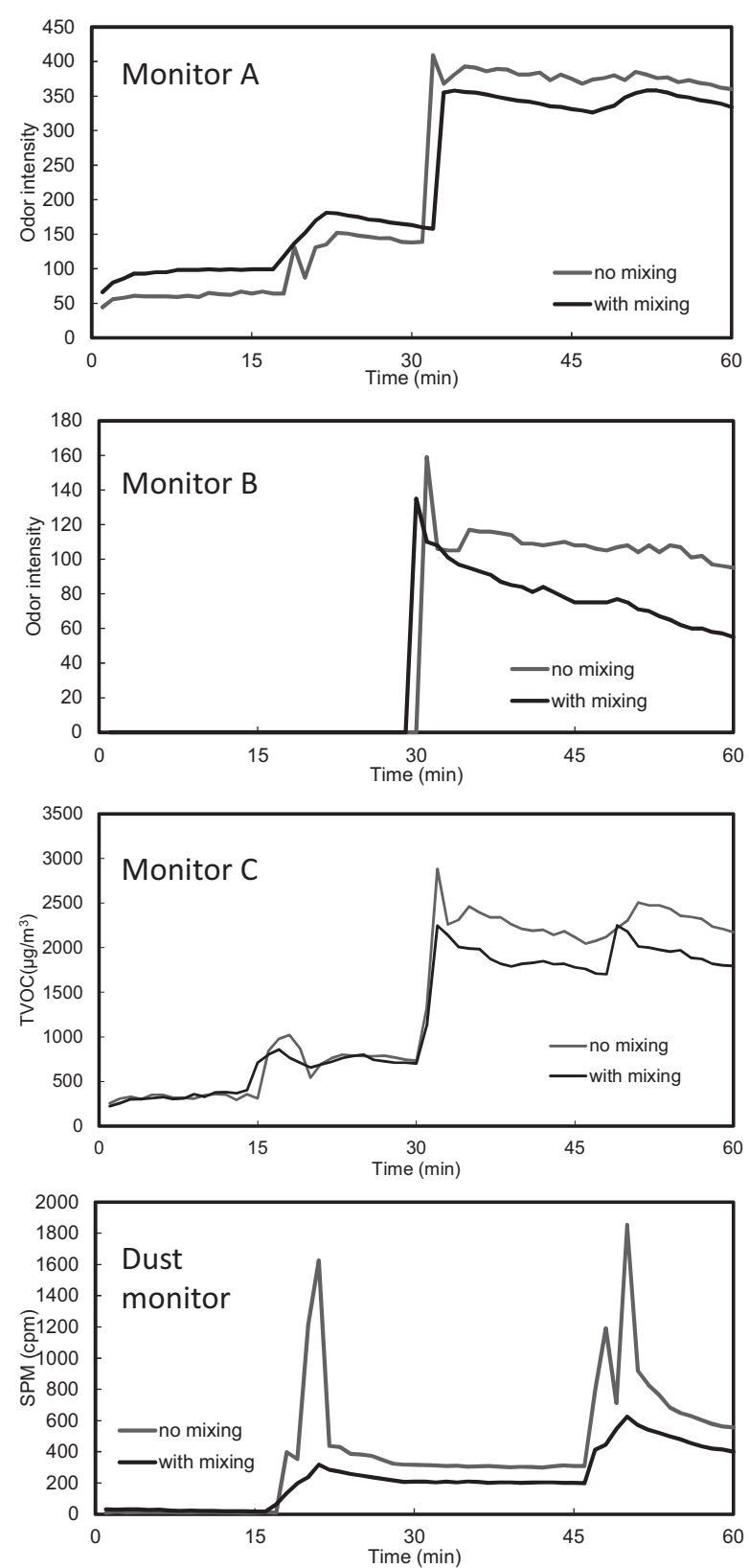

Fig.6 Responses of Monitors A, B, C and Dust monitor to ETS caused by active smoking, use of perfume and repeated active smoking with and without mixing by the fan in the closed room of apartment house (Case 2, January 5, 2014).

the room. The increases in baseline values suggest the monitors also responded to volatile chemicals emitted back into indoor air from surfaces by desorption and/or secondary formation of volatile compounds that were not originally present in fresh smoke ${ }^{9,16}$. It should be noted that the responses were not affected by the room mixing condition, unlike the SPM concentration measured by Dust monitor. Therefore, outputs by such gas monitors will be more robust than those by Dust monitor, when
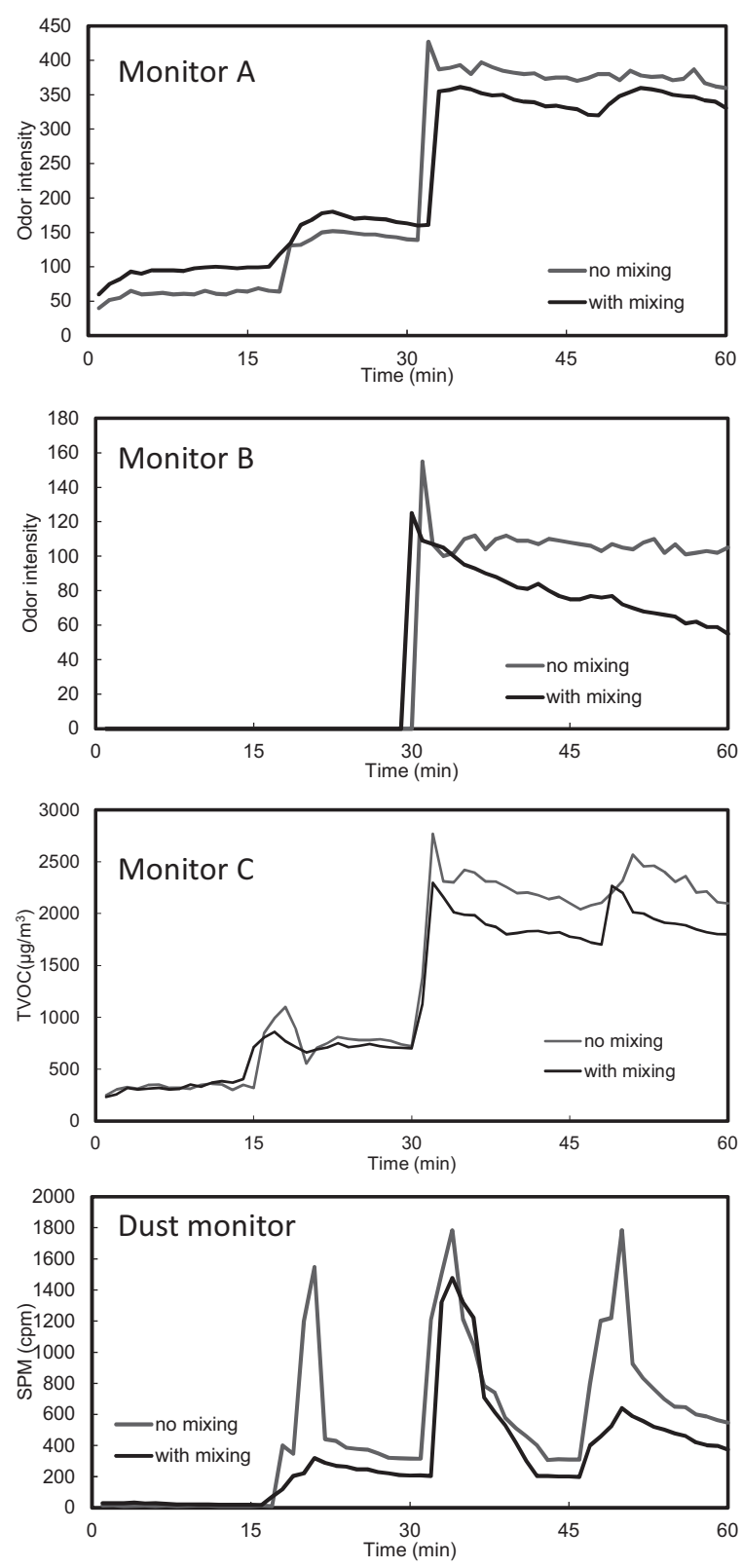

Fig.7 Responses of Monitors A, B, C and Dust monitor to ETS caused by active smoking, use of aerosol type antiperspirant and repeated active smoking with and without mixing by the fan in the closed room of apartment house (Case 3, December 21, 2013).

detecting the ETS in actual indoor environment.

However, Case II and III studies showed the both monitors were not specific to ETS; they also responded to volatile compounds originated from consumer products such as perfume and antiperspirant (non-ETS sources). Therefore, the false detection (response to nonETS) will be included in monitoring data when using Monitors A or C singly.

Meanwhile, Case II and III studies showed Monitor B, 
which did not respond to ETS, was sensitive to non-ETS gases in indoor air. Thus, the response caused by nonETS source can be excluded by combination of Monitors A or C and Monitor B. Even though Dust monitor responds to non-ETS source, synchronized responses with Monitors A and C may also help to identify the SHSoriented signals. Thus, the combination of different semiconductor monitors and Dust monitor may reduce the false detection in real-time monitoring data by separating ETS and non-ETS responses.

Although the present monitors used in this study are portable, it is very difficult to carry two or three monitors simultaneously, especially for children, expectant mothers, handicapped persons and the elderly. When applying to monitoring of personal exposure events to ETS, the monitors should be more compact and light for easy handlings.

\section{Conclusion}

Developing a methodology for real-time monitoring of exposure events to ETS, responses of three portable semiconductor monitors commercially available in Japan were tested in a smoker's room. The results showed the semiconductor monitors, except one model, successfully responded to the ETS and the responses were not affected by the room mixing condition. However, the monitors were not specific to ETS; they also responded to volatile compounds originated from non-ETS sources. Therefore, the use of gas monitor alone is not preferable for monitoring exposure events to ETS. Alternatively, the combination with other type monitors such as Dust monitor and gas monitors with different sensing performance may reduce false detections by separating ETS and non-ETS responses in monitoring data. However, we have to say carrying two or three monitors together is not practical for monitoring of personal exposure event to ETS at present.

\section{Acknowledgement}

This study was conducted as a part of Comprehensive Study on the Social Acceptance of Environmental Tobacco Smoke Evaluated from the Personal Exposure and Perception, supported by Smoking Research Foundation. Authors awfully thank Mr. Yohei Maezawa, Department of Chemistry, School of Science, Tokai University, for his great helps in the field test.

\section{References}

1) World Health Organization: WHO Report on the Global Tobacco Epidemic, 2009: Implementing smoke-free environments (2010).

2) Vainiotalo S., Vaaranrinta R., Tornaeus J., Aremo N., Hase T. and Reltonen K.: Passive monitoring for 3-ethenylpyridine: A marker for environmental tobacco smoke, Environ. Sci. Technol., 35, 1818-1822 (2001).

3) Ogden M. W. and Maiolo K. C.: Comparative evaluation of diffusive and active sampling systems for determining airborne nicotine and 3ethenylpyridine, Environ. Sci. Technol., 26, 12261234 (1992).

4) Saito I., Onuki A., Seto H., Hosaka M., Nakae D.: Development and application of a novel simultaneous measurement method for 3-ethenylpyridine and nicotine in air using alkaline-coated cartridge, Indoor Environment, 13(2), 173-179 (2010).

5) Akiyama Y.: Measurement manual of personal exposure to environmental tobacco smoke in daily life, nicotine, 3-ethenylpyridine / Active method, Indoor Environment, 13, Supplement, 11-16 (2010)

6) Ishizu Y.: Measurement manual of personal exposure to environmental tobacco smoke in daily life, nicotine, 3-ethenylpyridine / Passive method, Indoor Environment, 13, Supplement, 17-21 (2010).

7) Huynh C. K., Moix J.B. and Dubuis A.: Development and application of the passive smoking monitor MoNIC, Rev. Med. Suisse, 4(144), 430-433 (2008).

8) Arashidani K., Akiyama Y., Matsui Y.: Chapter 6 Method for investigating personal exposure, Evaluation of personal exposure to environmental tobacco smoke in daily life, Smoking Research Foundation, pp81-90 (2012).

9) Acuff L., Fristoe K., Hamblen J., Smith M., Chen J.: Third-Hand Smoke: Old Smoke, New Concerns, J. Community Health (2015), DOI: 10.1007/s10900015-0114-1.

10) Sleiman M., Logue J., Luo W., Pankow J. F., 
Gundel L., Destaillats H.: Inhalable constituents of thirdhand tobacco smoke: Chemical characterization and health impact considerations, Environmental Science and Technology, 48(22), 1309313101 (2014).

11) Matt G. E., Quintana P. J., Hovell M. F., Bernert J. T., Song S., Novianti N., Juarez T., Floro J., Gehrman C., Garcia M., Larson S.: Households contaminated by environmental tobacco smoke: Sources of infant exposure, Tobacco Control, 13(1), 29-37 (2004).

12) Kato K., Setoguchi Y., A semiconductor gas sensor for odor sensing, Journal of Japan Association on Odor Environment, 37(3), 190-194 (2006).

13) Yang S. B., Yu M. S., Sung B., Lee J., Jeon S, Yu M. S.: Correlation between the olfactory measurement value and odor sensor value for tobacco adhe- sion odor, Proceedings of 25th Annual Conference on Odor Environment, 98-100 (2012).

14) Fusaya M., Amagai T., Matsushita H., Soma M.: Study on evaluation methodology for complex odor using odor sensor (II) relationship between response values of odor sensor and odor index, Journal of Japan Society for Atmospheric Environment, 34 (1), 17-24 (1999).

15) Kasuga H.: Fundamental Study on passive smoking, Smoking Research Foundation Homepage, http:// www.srf.or.jp/histoly/papers/21.html.

16) Sleiman M., Gundel L. A., Pankow J. F., Jacob, P., III, Singer, B.C., Destaillats, H., Formation of carcinogens indoors by surface-mediated reactions of nicotine with nitrous acid, leading to potential thirdhand smoke hazards, Proc. Natl. Acad. Sci. U.S.A., 107, 6576-6581 (2010). 